\title{
BRUXAS E BRUXARIAS NA ILHA DA PINTADA
}

\author{
Susana de Azevedo Araújo \\ Universidade Federal do Rio Grande do Sul
}

Resumo: Este estudo versa sobre crenças e práticas religiosas em Porto Alegre, Rio Grande do Sul. Centra-se na análise de narrativas sobre bruxas e bruxarias, formuladas por pessoas que pertencem a uma mesma rede de relaçõesde vizinhança. Volta-se para uma análise do ethos popular e da visão de mundo dos ilhéus da Ilha da Pintada, Porto Alegre, procurando enfatizar os aspectos simbólicos que podem ser detectados através de suas crenças e da observação de suas práticas rituais. Ressalta as formas de sociabilidade e de relações e vizinhanças locais, bem como as distinções de gênero e de identidade onde ocorrem as narrativas de bruxas e bruxarias. Através da observação dos tipos de relacionamento entre os personagens envolvidos nos casos de embruxamento, ou seja, acusadores, acusados e vítimas, percebem-se as alianças e rivalidades dentro do grupo. Assim, a crença na bruxaria demarca fronteirassimbólicas, onde perpassamquestões de alteridadee sentimentos de pertencimento familiar.

Palavras-chave: bruxaria, bruxas, catolicismo popular, narrativas.

Keywords: narratives, popular Catholicism, witches, witchcraft.

O objeto desta pesquisa é o sistema de crenças e representações que envolvem as narrativas de bruxas e lobisomens contadas na Ilha da Pintada, em Porto Alegre. Essas narrativas são vistas por alguns moradores do local como histórias reais, que estão presentes no seu cotidiano, organizando dessa forma seus códigos de conduta e suas práticas religiosas e sociais. Portanto, este estudo está voltado para uma análise do ethos e da visão de mundo dos ilhéus, enfatizando os aspectos simbólicos que podem ser detectados

\footnotetext{
* Doutoranda do Programa de Pós-Graduação em Antropologia Social
} 
através da verbalização de suas crenças e da observação de suas práticas e rituais (Geertz, 1978, p. 143).

A pesquisa constitui-se de 23 entrevistas gravadas e transcritas, em sua maioria com mulheres (donas-de-casa), quase todas casadas com pescadores. ${ }^{1}$ Foram realizadas coletivamen te, uma vez que este "estilo de vida" contempla uma grande sociabilidade de rua e de visitas entre vizinhos. Tal situação de campo expressa uma forte identificação do tema bruxaria com a afirmação de uma sociabilidade do grupo de parentesco e vizinhança ao exibir a confirmação das versōes contadas dos casos, entre parentes e testemunhos de vizinhos. Reconstituindo a genealogia das entrevistadas mais velhas percebi que elas pertencem a famílias que há várias gerações residem no local. Muitas delas são de ascendência portuguesa, ou açoriana, que foram os primeiros grupos a povoarem a Ilha da Pintada, no século XIX. ${ }^{2}$

\section{AS NARRATIVAS SOBRE BRUXAS E LOBISOMENS}

As crenças e práticas ligadas à bruxaria na Ilha da Pintada apresentamse na forma de linguagem narrativa. Os entrevistados adquiriram seus conhecimentos sobre bruxas e lobisomens através de relatos contados muitas vezes pelos mais velhos: avós que contam aos netos, mães que contam aos filhos, por exemplo. Contam casos que dizem ter acontecido na própria família ou com pessoas conhecidas. Essa é a forma preferencial pela qual os ilhéus vão se socializando nessas histórias, ao mesmo tempo em que vão aumentando seus conhecimentos sobre esses assuntos do sobrenatural, mas

${ }^{1}$ Alguns dos nomes citados neste trabalho foram modificados porque as pessoas não queriam ser identificadas.

${ }^{2}$ A história de ocupação da Ilha da Pintada foi descrita por Cláudia Tarragô (1985), em monografia não-publicada, feita sob orientação da professora Ieda Gutfriend, do IFCH/ UFRGS. As fontes primárias em que se apóia o trabalho são:

- Livro de Registro de Pescadores do Rio Grande do Sul, no 1, 1908. Capitania dos Portos, Porto Alegre.

-Livro de Assentos Eclesiásticos da Capela Grande de Viamão, 1799. Cúria Metropolitana de Porto Alegre. 
que, no entanto, não deixam muitas vezes de atingir o seu cotidiano. $\mathrm{O}$ relato de dona Alice, 75 anos, benzedeira, ${ }^{3}$ demonstra uma situação recorrente que verifiquei em campo, ou seja, de como se dá à socialização da bruxaria na Ilha para a grande parte dos meus informantes. Quando the perguntei sobre qual teria sido a primeira vez que ela ouviu falar em bruxaria, sua resposta foi a seguinte:

[...] desde o tempo antigo né... minha vó contava, minha mãe, eu já vi... desde pequena, porque a mãe e o pai sempre me contavam que eu fui embruxada... a mãe não acreditava neste negócio de batuque, ${ }^{4}$ aí uma vizinha disse: "Não, deixa que eu levo ela lá", diz lá que me jogavam um pro outro, aí eu fiquei boa... (Alice, benzedeira, 75 anos).

Os estudos sobre bruxaria contemporânea, como de Favret-Saada (1977) e Maluf (1993), reforçam que a bruxaria se constitui enquanto fenômeno social na linguagem. As situações propícias, no entanto, para a

${ }^{3}$ Durante o trabalho de campo foram entrevistadas 11 benzedeiras: sete se declararam católicas, três umbandistas, e uma católica convertida ao pentecostalismo. Todas conheciam casos de bruxaria e embruxamento infantil.

${ }^{4}$ Segundo N. Corrêa, existem três formas rituais afro-brasileiras básicas no Rio Grande do Sul: a umbanda "pura", a linha cruzada e o batuque "puro". Essas denominações são dadas pelos próprios fiéis dos cultos, que têm em comum o elemento possessão, ou seja, seus filiados podem ser possuídos por divindades variadas que se manifestam através de seus corpos e mentes. Sendo assim: "A Umbanda pura congrega elementos católicos, kardecistas, de inspiração oriental, de inspiração indígena e o africano, sendo que neste tem predominância maior o de origem banto. E cultua: a) entidades católicas; b) espíritos de todas as categorias; c) en tidad es 'do Oriente'; d) caboclos; e) Orixás da 'Umbanda'. O Batuque Puro reúne elementos africanos de origem sudanesa e católicos. Assim cultua orixás e santos católicos (uns associados aos outros); em certas ocasiōes, também os eguns, os espíritos dos ancestrais 'de religião' dos praticantes. A Linha Cruzada cultua todo o universo de entidades das duas outras modalidade, a eles acrescentando as figuras do exu e da pombagira" (Cor rêa, 1994, p. 9-10). A umbanda, segundo Corrêa, tem origem no Sudeste brasileiro, provavelmente Rio de Janeiro. Enquanto a linha cruzada parece ter se difundido em cada região com formas já ali existentes, resultando em variaçôes regionais, como é o caso do Rio Grande do Sul. Há uma controvérsia sobre a origem do batuque do Rio Grande do Sul; ver Oro (1994). 
elaboração de um discurso narrativo sobre bruxas ou lobisomens, varia de acordo com os contextos da produção discursiva. O que Maluf vai chamar de situações de performance das narrativas. O termo performance é utilizado para designar "a realização das narrativas nas suas 'condiçôes reais' de existência, ou seja, o momento em que está montado um 'cenário' apropriado ou favorável para que as histórias e os relatos sobre as bruxas sejam contados" (Maluf, 1993, p. 85). São nesses momen tos que a bruxaria se configura enquanto um acontecimento social dentro da comunidade.

Os contextos favoráveis para que sejam contadas histórias sobre bruxas e lobisomens varia de acordo com os narradores e protagonistas das narrativas, bem como do envolvimento específico que esses têm com os casos de bruxaria, ou seja, conforme quem fala e as circunstânciasem que fala (FavretSaada, 1977). Varia também segundo a interação que se estabelece em campo entre o etnógrafo e os informantes. Em um estudo como este, em que estou, de uma certa maneira, privilegiando narrativas de mulheres sobre bruxaria, é comum as histórias se passarem em torno de casos de embruxamento de crianças (Maluf, 1993).

Uma mulher grávida ou um "recém-nascido" que ainda não foi batizado podem propiciar situações de performance narrativa entre mulheres, não precisando haver ainda um embruxamento de fato. Quando este ocorre, ele é evidenciado por uma série de sintomas que a criança apresenta, que são tomados como signos reveladores de uma ação de bruxaria. Mas a única pessoa na comunidade que pode confirmar, ou não, se uma criança está embruxada é a benzedeira, um personagem fundamental das narrativas de mulheres sobre bruxaria.

A. Quintana, inspirado no estudo de Favret-Saada (1977), sustenta a existência de uma relação assimétrica entre benzedeira e cliente, na qual a benzedeira ocupa o lugar de sujeito do suposto poder:

desenfeitiçar, não consiste em dizer fórmulas, nem em praticar rituais mágicos. Para que eles tenham alguma chance de serem eficazes, é preciso antes de tudo que seja instituído um sistema de lugares, graças ao qual alguém diferente do mágico, coloque este na posição de sujeito do suposto poder, é preciso ainda que o próprio mágico reconheça que ele ocupa este lugar, aceitando o 
que isto implica de engajamento pessoal num discurso, de assumir os efeitos da palavra mágica sobre seu próprio corpo, etc. (Favret-Saada, 1977, p. 42 apud Quintana, 1998, f. 137).

Tal como no estudo de Favret-Saada, para que a bruxaria seja instituída é necessária a palavra autorizada do enunciador. Segundo Quintana, esse lugar de autoridade em relação ao consulente não é algo exclusivo da prática da benzedeira; ele também está presente no atendimento médico, "ainda que nele se acredite real e não imagi nário” (Quintana, 1998, f. 138).

\section{OS DISCURSOS SOBRE BRUXAS E LOBISOMENS}

Os discursos sobre bruxas e lobisomens na Ilha da Pintada podem ser divididos em dois tipos. Um discurso geral sobre esses personagens das histórias, que aponta para caracterizações e conhecimentos de como são esses seres, o que fazem e porque agem de determinadas maneiras, e discursos narrativos sobre casos de bruxaria, os quais podem ser subdivididos em depoimentos pessoais, onde os próprios narradores são os personagens das narrativas, e casos que se passaram com outros, pessoas conhecidas, geralmente da família. Os exemplos que seguem ilustram, respectivamente as duas possibilidades:

Tu sabe que isso aí é um fardo, uma coisa que é dos antigos né, quando a mãe tem corrido sete filhas, ou sete filhos homem, entendeu, aí pode contar que a primeira ou a última é. É a coisa mais certa, se tu quer descobrir. Porque elas fazem assim, elas viram tudo de boca pra baixo, tudo que tem dentro de casa, elas não gostam de nada virado normal é tudo emborcado... (Rosa, benzedeira, 57 anos).

Olha um caso assim bem verdadeiro que eu vou te contar foi do meu irmão. Ele perdeu um gurizinho embruxado, a bruxa embruxou ele e matou, aqui na Ilha, e ele chegava a ficar só de cueca porque diziam que se ficava só de cueca ela vinha. Elas passavam a cavalo dando risadas, guria, aqui na Pintada... O gurizinho do Pedro, foi verdadeiro isso, ele morreu na última, chupadinho 
de sangue das bruxas. Ele se armava pra pegar elas... elas pegavam as crinas dos cavalos e trançavam que aparecia no outro dia... elas trançavam eles, só que agora já não existe muito, né... mas ainda tem por aí... tu sabe que ela se vira numa borboleta... (Teresa, 64 anos).

O lobisomem não te faz nada, ele vira num cachorro. $\mathrm{O}$ meu pai viu um uma vez... esse lugar mesmo aqui não tinha casa nenhuma, só a minha vó que morava. Eu era pequena, guria ainda... Quando meu pai entrou perdeu os tamancos, perdeu tudo... Ele veio saindo fora de hora, ele tava visitando uns amigos e passou do horário e quando vinha vindo, desconfiou que tinha alguém seguindo ele; diz que olhou assim, aquele troço acompanhando ele. Quanto mais ele olhava mais crescia, parecia um terneiro, crescia mais, e os cabelos dos braços dele levantava. E ele disse: "Iisso é coisa de outro mundo!" e bateu perna e perdeu os tamancos. No outro dia, fomos eu e minha irmã procurar os tamancos do meu pai... Ele meteu a porta da casa da falecida vó pra dentro. Ela perguntou: "O que é isso?" Ele disse: "Eu vi uma coisa agora que eu nunca vi na minha vida, o tal de lobisomem..." A minha avó abriu a janela e perguntou: "Cadêe?" Ele disse: "Ué, não tá mais." Ele se some, veio até a porta da casa acompanhando o meu pai. Era como um terneiro, ele disse que olhava e se arrepiava. Ele se transforma em cachorro, terneiro, porco, tudo... (Julieta, benzedeira, 58 anos).

Nesses depoimentos se evidenciam conhecimentos gerais adquiridos sobre bruxas e lobisomens, uma espécie de aprendizado que é transmitido através das geraçôes, capacitando os ilhéus a terem um corpus de conhecimentos nesses assuntos. Também, nos depoimentos, aparece a advertência dos perigos que representam a bruxaria na comunidade, podendo ocasionar a morte de crianças. Na Europa dos séculos XVI, XVII e XVIII, segundo Souza (1986), uma das crenças mais generalizadas a respeito de bruxas era sua atuação como assassinas de crianças, sendo o infanticídio, certamente, um dos crimes mais imputados às bruxas.

Os personagens das histórias, bruxas e lobisomens, fazem parte de um núcleo mítico comum que é datado por volta dos séculos XV, XVI e XVII. São, na perspectiva de Ginzburg (1991), o resultado híbrido de um conflito entre cultura folclórica e cultura erudita. As crenças camponesas de que 
era necessário o resguardo da fertilidade dos campos fazia com que os benandanti lutassem contra bruxas e feiticeiros que atacavam à noite. Segundo Ginzburg:

Com esse termo (benandanti), eram designados no Friul, entre os séculos XVI e o XVII, aqueles (tratava-se, em sua maioria,de mulheres) que afirmavam assistir periodicamente às procissões dos mortos. Mas do mesmo modo eram chamados também outros indivíduos (em grande parte homens) que afirmavam combater de tempos em tempos, armados com ramos de erva doce, pela fertilidade dos campos, contra bruxas e feiticeiros armados de caule de cevada. $\mathrm{O}$ nome, o signo que identificava materialmente um e outro gênero de benandanti (ter nascido com o pelico ${ }^{5}$ ); o período (os quatro tempos) em que, de modo geral, executavam as proezas a que estavam destinados; o estado de letargia que as precedia eram, em ambos os casos, idênticos. $\mathrm{O}$ espírito dos (ou das) benandanti deixava por algum tempo o corpo exânime, às vezes em forma de rato ou borboleta, em outras ocasióes na garupa de lebres, gatos e outros animais, para dirigir-se em êxtase rumo às procissões dos mortos ou às batalhas noturnas contra bruxas e feiticeiros (Ginzburg, 1991, p. 143).

Benandanti e lobisomens, segundo o autor, apresentavam-se como figuras benéficas, depositárias de um poder extraordinário. Aos olhos da comunidade da época, porém, esse poder era intrinsecamenteambíguo, pronto a transformar-se em seu contrário. Uma ambivalência simbólica que talvez caracterizasse os comportamentos diurnos desses personagens. $\mathrm{O}$ confronto com uma cultura erudita, no caso a Igreja, em meados do século XV, vai fazer com que o halo contraditório que circunda esses seres ambíguos, "ao mesmo tempo humanos e bestiais" (Ginzburg, 1991, p. 143), seja progressivamente cancelado pela sobreposição de um estereótipo feroz, que vai cristalizar a imagem hostil tanto da bruxa quanto do lobisomem mais ou

\footnotetext{
${ }^{5}$ Envoltório do feto no ventre materno.
} 
menos no mesmo período histórico. ${ }^{6}$ Apesar da distância histórica que nos separa do período moderno, um substrato de crenças se faz presente nos dias de hoje, mesmo quando uma atitude científica e racional predomina há séculos.

Segundo Maluf, as narrativas comportam-se como "dramas sociais", inspirando-se nos estudos de Turner (1981) sobre narrativas: "o drama significa u ma 'qu ebra da norma', u m momento de 'virada nas relaçóes entre os componentes do campo social" (Maluf, 1993, p. 60). Essa desordem ou inversão das regras sociais só é percebida porque existia uma situação de equilíbrio anterior. Outra característica das narrativas é que elas possuem em comum uma estrutura que vai além de uma simples sucessão de açôes no sentido início, meio e fim. O que define uma narrativa, para Todorov (1981), é a relação de transformação das unidades que a compõem. Sendo assim, as narrativas sobre bruxas e lobisomens podem ser tomadas como variações de algumas poucas histórias que são sempre recontadas.

Maluf (1993, p. 61), utilizando o esquema proposto por Todorov de análise narrativa, divide em cinco funções básicas as narrativas de bruxaria, que passo agora a utilizar para as narrativas de lobisomens existentes na Ilha da Pintada:

\footnotetext{
6 "Em 1581, dois benandanti foram condenados como hereges a seis meses de prisão e obrigados a retratação de seus erros... em conseqüên cia dos vários julgamentos os benandanti começaram a aceitar o modelo demonológico que a Inquisição persistia em lhes imputar. A partir de um certo momento não ouvimos mais falar do rito central de fertilidade. Depois de 1600, os benandanti admitiam que praticavam apenas a cura das vítimas dos feiticeiros. Tal concessão tinha seus perigos porque a Inquisição considerava a habilidade de curar maus feitiços como provas óbvias de bruxaria. Com o passar do tempo, os benandanti não só se tornaram cônscios de sua importância; eles passaram a multiplicar suas denúncias daquelas pessoas supostamente conhecidas como bruxas por eles. Apesar desse antagonismo exacerbado, contudo, os benandanti foram inconscientemente, se aproximando dos strighe stregoni. Em 1618, uma mulher benandanti admitiu ter comparecido a um Sabá noturno presidido pelo Demônio, acrescentando, contudo, ter feito isso para obter o poder de cura. Finalmente, em 1634, após cinqüenta anos de julgamentos pela Inquisição, os benandanti reconheceram sua identidade com os feiticeiros (strighe e stregoni)." (Eliade, 1979, p. 84).
} 
1) a situação de equilíbrio inicial [de ordem anterior];

2) a degradação da situação [o homem desconfia que o estão seguindo];

3) o estado de desequilíbrio [o medo e a vontade de ver quem o está seguindo];

4) a procura e a descoberta [olha para trás com o intuito de ver quem o está seguindo, assusta-se e corre até a casa];

5) o restabelecimento do equilíbrio inicial [chega em casa, conta para a mãe e esta diz que não viu nada].

Mudam os lugares, os protagonistas, o momento e alguns detalhes significativos, mas o núcleo dramático e a estrutura geral que serve como base da narrativa se mantêm, a não ser quanto ao desfecho da trama, que pode mudar de uma história para outra. No caso de narrativas sobre embruxamento infantil, o desfecho pode ser ou a morte da criança ou a cura, como se verá a seguir. A narradora é a mãe da criança, que depois de levar a filha aos médicos, e esses não diagnosticarem a doença, conclui que só pode ser bruxaria.

Ela tava embruxada antes dela nascer. Dentro da minha barriga... Eu fui descobrir mesmo quando ela tinha uns nove meses...Levei no Presidente Vargas [hospital], na Santa Casa, eles só diziam que tinha que fazer exames nela, só furando a guria, tirando sangue, fazendo exame de urina... e não descobriam o que ela tinha. Eles inventaram umas histórias, mas eu já nem acreditava. Houve uma época que eu até achava que a guria tinha alguma doença ruim. A guria não dormia, não comia comida, era só leite puro, não dormia, só chorava a noite todinha. [...] A tia Alice vinha aqui em casa e dizia pra mim: "Neca, quem sabe a gente não benze essa guria, quem sabe essa guria não é embruxada." Eu dizia: "Capaz ,tia Alice, essas coisas não existe!" Ela dizia: "Existe sim, Neca, isso aí existe!" Aí ela agarrou e mandou as crianças pegar as coisas pra benzer ela. Ela disse pra mim: "Olha eu vou benzer ela sete dias, tu vai ver que dentro desses sete dias ela vai começar a desenvolver..." Ela começou a benzer, os sete dias ela benzeu e a guria co meçou a comer comida de sal, já começou a sentar, e foi só desenvolvendo. [...] Ela disse que quando olhava pra ela, dizia que tinha uma velha nela... a gente olhava pra ela e tinha vontade de chorar. Até eu às vezes me assustava da guria de noite. (Marilise, 26 anos).

Debates do NER, Porto Alegre, ANo 5, N. 5, P. 57-75, JUnho 2004 
É necessário, antes de decompor essa narrativa, fornecer alguns dados sobre essa informante. Marilise mora na Ilha da Pintada há quatro anos. Nasceu em Lajeado, interior do Rio Grande do Sul, e até então nunca tinha ouvido falar de bruxaria, o que a difere das outras mulheres que nasceram e se criaram na Ilha. Seu marido, ao contrário, nasceu e se criou no local. Quem a informou sobre a possibilidade do embruxamento de sua filha foi uma benzedeira, dona Alice, avó de uma vizinha de Marilise que, ao visitar a neta, Iva, examinou a criança e anunciou à mãe que ela estava embruxada. Ocorre, nessa situação específica, o que Favret-Saada designa de momento da enunciação: "aquele onde os enfeitiçados curados de seus males vêm an unciar a outros infelizes - supostos não ter pensado jamais nisso ou ouvido falar disso - que são atingidos, por sua vez, pelos sortilégios" (FavretSaada, 1977, p. 81, tradução minha).

A existência de um prólogo, que antecede uma seqüência narrativa, se faz presente nessa situação particular, talvez por Marilise não ter sido socializada nessas histórias desde a infância. Ou seja, se verificam aqui as fases, segundo Favret-Saada (1977), que introduzem uma narrativa de bruxaria e feitiçaria: ${ }^{7}$ 1) a negação inaugural - quando Marilise diz que isso (bruxaria) não existe; 2) a observação do desvio do saber positivo - os médicos não acertam o diagnóstico da doença; 3) a animação solene do estado de enfeitiçado - quando a benzedeira visita a criança e identifica que é bruxaria, prescrevendo um tratamento ritual.

Em seguida, ocorrem as cinco fases que normalmente compõem esse gênero de narrativa, estudado por Favret-Saada (1977, p. 82), e que procuro adaptar para o caso específico da Ilha:

\footnotetext{
7 E. Evans-Pritchard distingue bruxaria de feitiçaria. A bruxaria é uma ação involuntária e inconsciente de algumas pessoas, um poder psicofísico hereditário. Já a feitiçaria é uma ação voluntária e consciente aprendida através de ensinamentos. O feiticeiro utiliza a técnica da magia no sentido negativo. Ambas, bruxaria e feitiçaria, são açōes moralmente condenáveis na cultura Zande, e são o contrário da (e contrariadas pela) boa magia (Evans-Pritchard, 1978).
} 
1) a procura da identidade do bruxo [no caso da Ilha a bruxa é sempre uma mulher];

2) a indicação dos meios de lhe perguntar e se defender dos seus malefícios;

3) a execução de um ritual mágico e a adoção de maneiras características de se comportar;

4) a interpretação dos efeitos produzidos, isto é, para o bruxo, o desvio

(a morte, a doença ou a falência) e, para o enfeitiçado, o retomo progressivo à vida normal;

5) enfim, a manutenção de uma transferência indefinida entre, no caso, o curandeiro e seu cliente.

Esse esquema parece-me mais apropriado para as narrativas de mulheres sobre bruxas e bruxarias na Ilha da Pintada, uma vez que existem acusações de bruxaria com a indicação dos acusados pelos informantes. Já o esquema proposto por Maluf (1993) se adequou tanto às narrativas de lobisomens quanto de bruxaria, no que se refere às distinções de gênero e identidade subjacentes às narrativas trabalhadas pela autora.

\section{FORMAS DE PODER: MASCULINO X FEMININO}

As narrativas sobre bruxas e lobisomens na Ilha não devem ser consideradas como sobrevivência do passado que ainda atua nos dias de hoje. Elas trazem à tona contrad ições subjacentes à organização social; são estruturantes da cultura. Para Maluf, nesses discursos está implícita uma construção de identidade e gênero. No grupo social por ela analisado, aparentemente a autoridade masculina - tanto na família quanto no grupo não é questionada; as narrativas de bruxas e bruxarias estabelecem um paradoxo, uma vez que nelas a bruxa é apresentada como uma figura feminina poderosa. "A bruxa, dentro das narrativas, fala precisamente deste universo feminino que os modelos conscientemente assumidos não dão conta: um universo in compreen sível e perigoso.” (Maluf, 1993, p. 14). 
Como já foi dito, as narrativas mudam conforme os narradores e protagonistas das histórias. Sendo assim, os homens geralmente narram casos em que as bruxas ameaçam os espaços masculinos; elas aparecem à noite, na estrada (um território que durante a noite é masculino), e impedem o trabalho dos pescadores roubando sua canoa para passear, colocando à prova a sua autoridade. Todas essas histórias se passam durante a noite, existindo uma dimensão de orgia e erotismo. Quando são as mulheres que contam as histórias, estas se referem principalmente a casos de embruxamento de crianças (a bruxa sempre ataca a criança dentro da casa, um território considerado eminentemente feminino).

Assim, se verifica subjacente a essas narrativas uma situação de conflito e rivalidade entre mulheres. Aqui se pode relacionar com os estudos de E. Evans-Pritchard (1978) sobre bruxaria entre os Azande, onde esta é associada a noções de infortúnio e doença, de rivalidades entre vizinhos, ciúmes e contendas. As bruxas colocam em jogo a autoridade das mulheres sobre o resguardo do lar, ao passo que entre os homens elas provocam o medo de um mundo feminino desconhecido (Maluf, 1993).

Diria que as narrativas de lobisomens estão inseridas nesse mesmo complexo, no jogo da construção das identidades masculina e feminina dos ilhéus. As histórias de lobisomens ocorreram paralelas às narrativas de bruxaria; um assunto sempre implicava o outro. Podemos evidenciar nessas narrativas vários pares de oposição entre esses dois personagens, ou seja, princípios de classificação que organizam as práticas e as crenças dos ilhéus: (bruxa x lobisomem); (casa x rua); (feminino x masculino); (dia x noite); (imanência $x$ transcendência). As bruxas, mesmo andando à noite na rua (o que gera uma inversão de papéis, pois as mulheres costumam ficar em casa à noite, por considerá-la perigosa e desconhecida), podem entrar dentro das casas para embruxar as crianças, enquanto que os lobisomens ficam apenas na rua, um lugar tido como masculino, e nunca entram dentro das casas; no máximo andam em volta, assustando as mulheres. A bruxa pode atacar a qualquer hora do dia (embora os ataques sejam mais freqüentes durante a noite), lançando um "mau-olhado" ao simplesmente visitar u ma criança. Os lobisomens, por sua vez, só saem à noite. As cores também 
parecem entrar nestas classificações. Os lobisomens geralmente são pretos, ou marrom escuro, enquanto que as bruxas, quando vistas, estão de branco, geralmente de camisola. As metamorfoses por que passam esses personagens também são significativas: as bruxas se transformam em borboletas, moscas, aves, etc., e estão associadas simbolicamente a gatos. Darton (1986) chama a atenção para costumes e crenças tradicionais européias que remontam à Idade Média e início dos tempos modernos sobre os vários aspectos simbólicos desse animal:

Antes de mais nada, os gatos sugeriam feitiçaria. Cruzar com um deles, à noite, praticamente em qualquer parte da França, significava a arriscar-se a se deparar com o demônio, com um de seus agentes ou com uma feiticeira indo cumprir alguma malévola missão. Os gatos brancos podiam ser tão satânicos quanto os pretos, de dia ou de noite. Num encontro típico, uma camponesa de Bigorre encontrou um bonito gato branco, doméstico, que se perdera nos campos. Carregou-o de volta para aldeia em seu avental e assim que chegaram à casa de uma mulher suspeita de feitiçaria, o gato pulou para fora, dizendo "Merci, Jeanne." [...] Finalmente, o poder dos gatos concentrava-se no aspecto mais íntimo da vida doméstica: $\mathrm{O}$ sexo. Le chat, la chatte, le minet significam a mesma coisa, na gíria francesa, que "pussy" em inglês ["pussy" - expressão correspondente a órgãogenital feminino].O folclore francês atribui importância especial aos gatos como metáfora ou metonímia sexual... Em toda parte os gatos sugeriam fertilidade e sexualidade feminina. (Darton, 1986, p. 125-127).

Segundo Mauss e Hubert (1974, p. 66), as feiticeiras européias não tomam todas as formas animais: "Transformam-se regularmente, esta em jumento, aquela em rã, aquela outra em gato, etc.” Ou seja, a metamorfose equivale a uma associação com uma espécie animal. É assim que regularmente, também, os lobisomens transformam-se em cachor ros, lobos, terneiros, porcos, etc. Os animais associados a esses seres são uma espécie de totem individual, uma convenção social que contribui para determinar sua condição tanto de bruxa quanto de lobisomem.

As figuras da bruxa e do lobisomem revelam assim as distinções de gênero e identidade que estão implícitas na lógica do sistema social. 


\section{ACUSAÇÕES DE VIZINHOS, OU QUEM SÃO AS BRUXAS E OS LOBISOMENS DA ILHA}

A pesquisa revelou que os acusados dificilmente sofrem recriminações ou são evitados pelos outros por serem considerados bruxas ou lobisomens. Isso se deve, até certo ponto, à própria dinâmica das açōes de bruxaria, que é considerada como ação involuntária. Ou seja, qualquer mulher pode ser uma bruxa como qualquer homem pode ser um lobisomem. Durante o trabalho de campo registrei nove acusados, seis mulheres e três homens. Alguns deles são pessoas respeitadas na comunidade, participam da vida social na Ilha, freqüentam a Igreja Católica ou Evangélica, as festas religiosas e são solidários com a vizinhança local e esta com eles.

Mas há acusados que adquirem má reputação. É o caso de pessoas conhecidas na comunidade que entram constantemente em conflitos com os vizinhos por questôes de propriedade de terras, por rogarem pragas (algumas mulheres são conhecidas por terem "boca ruim"); outros são conhecidos por colocarem "olho-grande", ou mau-olhado, em plantas e pessoas. Essas pessoas são consideradas invejosas, ciumentas e descont roladas, freqüentemente acusadas, e sua "fama" de bruxa ou lobisomem na vizinhança é notória.

Pelo número de acusações e acusados que efetivamente chegaram até meu conhecimento, percebi que existem determinadas variáveis para a formação de uma identidade e imagem de bruxa ou lobisomem na Ilha. Muitas vezes, os traços que compõem a imagem dos acusados se sobrepõem em determinados indivíduos, reforçando as características de pessoas identificadas como tais na comunidade.

Mauss e Hubert chamam a atenção para o fato de que esses indivíduos formam, na realidade, como que classes sociais. "O que lhes dá virtudes mágicas não são tanto as suas características físicas individuais, quanto à atitude que a sociedade adota em relação a todo seu gênero" (Mauss; Hubert, 1974, p. 58). Portanto é a opinião pública que cria esses seres fantásticos, bem como as influências por eles exercidas.

Três dos nove acusados que tive a oportunidade de registrar receberam, segundo os ilhéus, o fardo dos parentes. No caso das mulheres, uma 
avó, mãe ou tia passa o fardo antes de morrer para a parenta mais "chegada" a ela. O mesmo vai se dar com o lobisomem: o fardo é passado geralmente pela linhagem masculina. Esse é o caso de Anselmo, 40 anos, pescador que recebeu o fardo de seu tio Cláudio, antes deste falecer.

Anselmo, assim como seu tio, nasceu na Ilha da Maria Conga (localizada em frente à Ilha da Pintada). Todos os moradores antigos afirmam que Cláudio era lobisomem, entre eles Pedro, 77 anos, pescador aposentado, que fez várias acusações. Ressalta o nome de Cláudio confirmando a sua fama:

Existia muito lobisomem aqui na Ilha, o Eleutério, o Cláudio da Vera, o falecido Chico depois que ficou com o fardo do pai dele... Agora aqui na Ilha há muita coisa, na pescaria teve gente que viu, né. Conhece o Néri, pai do Dorival, aquele lá de baixo, pescador... aquele tava na pescaria com o Cláudio da Vera e o Cláudio parecia um animal remando, que tinha que chegar em casa... era uma sexta-feira e escurecia, então ele tinha tambo ${ }^{8}$ do lado de lá da Conga, quando saltou da canoa se mandou direto à cocheira. Se virou no bicho lá na cocheira, não falou pra ninguém e eles ficaram na praia, ele o Dorival e o outro. Foram fazer café, já era noite e era aquela barulhada de vaca, terneiro e cachorro na cocheira, aí terminou aquela zoada toda e eles foram lá pra dentro de casa falar com a mulher do Cláudio, e perguntaram: "Cadê o Cláudio?" "Ah, o Cláudio tá lá na cocheira"... (Pedro, 77 anos).

Interessante notar que quando visitei a Ilha da Conga para entrevistar alguns moradores entrei logo em contato com os filhos de Cláudio, que também são pescadores, e estes não me contaram nenhum caso de lobisomem, nem sequer mencionaram o nome de seu pai. Anselmo, que teria recebido, segundo os ilhéus, o fardo de Cláudio, possui as unhas dos pés compridas, é um homem de poucas palavras. Sua imagem de lobisomem é reforçada em dois sentidos, ou seja, pela herança familiar (ao ter recebido o fardo de seu tio) e pelos traços físicos singulares, que facilitam a imputação de lobisomem.

${ }^{8}$ Casa de campo; barracão; estabelecimento onde se ordenham vacas, para venda de leite. 
Outro fator também relevante para uma acusação de bruxaria é a idade. Pessoas com mais de 80 anos estão sujeitas a sofrerem acusaçôes. Esse é o caso de Maria, 90 anos. Ao que consta, ela não tinha fama anterior de bruxa, mas o fato de estar doente há meses e não morrer fez com que ela começasse a ser vista como bruxa por alguns. Percebi que outros velhos da Ilha sofreram o mesmo tipo de acusação. Isso provavelmente está relacionado ao fato dos ilhéus acreditarem que enquanto a pessoa não passar para outra seu fardo ela não morrerá. Segundo a interpretação dos ilhéus:

$[\ldots]$ a bruxa a gente realmente descobre quando ela tá pra morrer porque ela fica penando em cima de uma cama, porque ela não morre assim; enquanto ela não passa o fardo pra outra ela não morre. (Carla, 22 anos).

A religiosidade é outro fator que também parece ser relevante para se verificar a relação entre acusadores e acusados. Os imunes são sempre católicos, ao passo que os acusados nem sempre são da mesma religião. Em alguns casos são pentecostais ou tiveram um trânsito pelo pentecostalismo.

Não verifiquei acusador es pentecostais. Isso se deve, em parte, à reinterpretação que a categoria bruxaria recebe nesses grupos. Há aqui um deslocamento da idéia de bruxaria para a de demônio.? Os demônios, nesse

9 Em outro estudo, A Reação dos Agentes do CatolicismoPopular Tradicionalao Pentecostalismo
(Araújo, 1997), verifiquei que a categoria bruxaria na Ilha da Pintada é percebida e
interpretada de modo diferente entre os católicos e os pentecostais do local. No primeiro
caso, como já mencionei, a bruxaria é considerada uma ação involuntária de algumas
mulheres e possui vítimas preferenciais: recém-nascidos e mulheres grávidas. A bruxaria
revela um sis tema de acusaçóes e "fofocas" en tre os ilhéus, sobre quem teria embruxado as
crianças, como desfazer esse embruxamento e quem seria a bruxa. Enquanto que entre os
pentecostais, esse fenômeno é reinterpretado e englobado junto a diferentes práticas de
adivinhação, sob a rubrica de manifestação demoníaca. A categoria bruxaria é deslocada
para a idéia de demônio. É como se o catolicismo tradicional praticado na Ilha perten-
cesse a uma tradição mais profunda, onde a categoria bruxaria faz parte do universo
cognitivo desses agentes do catolicismo popular tradicional e as narrativas sobre bruxas e
bruxarias constituíssem um modo destes ilhéus se pensarem enquanto grupo. Ao passo
que para os fiéis do pentecostalismo, esta categoria parece não mais estar presente da mes-
ma forma, havendo sempre um deslocamento da idéia de bruxaria para a idéia de demônio. 
sentido, estariam em toda parte, tentando afastar o homem da palavra de Deus, representando uma ameaça constante para os fiéis, numa lógica de confronto entre o bem e o mal, Deus como representante único do bem e o mal representado pelos demônios. Entre os membros do catolicismo tradicional na Ilha da Pintada, a idéia de demônio dificilmente é acionada nas narrativas de bruxas e bruxarias. ${ }^{10}$

Essas são, pois, algumas variáveis verificadas durante a pesquisa e que contribuem para as acusações de bruxaria na Ilha. Porém, dentre todos os fatores o único que invariavelmente está presente em todos os casos analisados é o de que a bruxaria e as acusações estão relacionadas às relações de vizinhança. Esse fato está de acordo com o ensinamento de Evans-Pritchard, para quem as pessoas "tenderiam a entrar em disputas com aqueles que estão mais próximos quando esta proximidade não é atenuada por sentimentos de parentesco, ou tornada irrelevante por distinçôes de idade, sexo ou classe" (Evans-Pritchard, 1978, p. 88). O que pude evidenciar através da genealogia dos entrevistados é que as pessoas acusadas de bruxas ou lobisomens não têm uma relação de parentescoconsangüíneo ou ritual com aquelas que as estão acusando. Em nenhum caso houve acusações de parentes consangüíneos, mesmo quando entrevistava pessoas que sabia que tinham acusados em sua família. Acusavam-se vizinhos, mas nunca parentes. Notei também que não há distância quanto ao poder aquisitivo entre os acusados e os acusadores. Além disso, há sim uma referência cultural comum: todos, de uma forma ou de outra, já ouviram falar de histórias de bruxas e lobisomens.

\footnotetext{
${ }^{10}$ A bruxaria é anterior ao catolicismo, sendo o demônio uma introdução da cultura erudita - séculos XVI, XVII e XVIII - para justificar as pers eguiçóes e caça às bruxas (Gin zburg, 1991).
} 


\section{REFERENNCIAS}

ARAÚJO, Susana de Azevedo. A reação dos agentes do catolicismo popular ao pentecostalismo. Debates do Ner, Porto Alegre, ano 1, n. 1, p. 77-79, 1997.

CORRÊA, Norton Figueiredo. Panorama das religiōes afro-brasileiras do Rio Grande do Sul. In: ORO, Ari Pedro (Org.). As religióes afro-brasileiras do Rio Grande do Sul. Porto Alegre: Ed. UFRGS, 1994. p. 9-46.

DARTON, Robert. O grande massacre de gatos, e outros episódios da história cultural francesa. Rio de Janeiro: Graal, 1986.

ELIADE, Mircea. Ocultismo, bruxaria e correntes culturais: ensaios em religiōes comparadas. Belo Horizonte: Interlivros, 1979.

EVANS-PRITCHARD, E. Bruxaria, oráculos e magia entre os Azande. Rio de Janeiro: Jorge Zahar, 1978.

FAVRET-SAADA, Jeanne. Les mots, la mort, les sorts. Paris: Gallimard, 1977.

GEERTZ, Clifford. A interpretação das culturas. Rio de Janeiro: Jorge Zahar, 1978.

GINZBURG, Carlo. História noturna: decifrando o Sabá. São Paulo: Companhia das Letras, 1991.

MALUF, Sônia. Encontros noturnos: bruxas e bruxarias na lagoa da Conceição. Rio de Janeiro: Rosa dos Tempos, 1993.

MAUSS, Marcel; HUBERT, H. Esboço de uma teoria geral da magia. In: MAUSS,Marcel. Sociologiae antropologia. São Paulo:EPU, 1974. p. 37-176.

QUINTANA, Alberto Manuel. A ciência da benzedura: de mau-olhado, rezas e simpatias. Tese (Doutorado em Ciências Socias)-Pontifícia Universidade Católica de São Paulo, São Paulo, 1998.

SOUZA, Laura de Mello e. O diabo e a terra de Santa Cruz feitiçaria e religiosidade popular no Brasil colonial. São Paulo: Companhia das Letras, 1986. 
TARRAGÔ, Claudia. A presença do elemento açoriano no povoamento da ilha da Pintada. Monografia (Técnica de Pesquisa)-Instituto de Filosofia e Ciências Humanas, Universidade Federal do Rio Grande do Sul, Porto Alegre, 1985.

TODOROV, Tzvetan. Os gêneros do discurso. Lisboa: Edições 70, 1981.

TURNER, Victor. Social dramas and stories about them. In: MITCHELL, W. J. T. (Org.). On narrative. Chicago: University of Chicago Press, 1981. p. 137-164. 